\title{
Analisis Wacana Kritis terhadap Berita Pembubaran Front Pembela Islam di Kompas.com
}

\author{
Critical Discourse Analysis on News of the Dissolution of the \\ Islamic Defenders Front on Kompas.com
}

\author{
Indah Suryawati* \& Jamalullail \\ Universitas Budi Luhur Jakarta, Jl. Ciledug Raya, Petukangan Utara, Jakarta Selatan, 12260 \\ Universitas Sahid Jakarta, Jl. Prof. DR. Soepomo No.84, Jakarta Selatan \\ *E-mail: Indah.suryawati@budiluhur.ac.id
}

Submitted: 22-02-2021, Revised: 09-04-2021, Accepted: 10-05-2021, Published: 19-07-2021

Doi: https://doi.org/10.33508/jk.v10i1.3040

\begin{abstract}
The government's decision regarding the dissolution and termination of all FPI activities raises pro and contra among the media and the public. The dissolution of FPI was decided by means of a decree signed by six ministers and heads of state institutions. This study aims to describe and dismantle the discourse of the news text on the decision to dissolve FPI using Critical Discourse Analysis (CDA). The research method used is Norman Fairclough's Critical Discourse Analysis through understanding text and context. There are five steps that are used as a reference. First, focus on social irregularities in its semiotic aspects. Second, identify barriers to address the social irregularities. Third, consider whether social order requires social irregularity. Fourth, identify possible ways to overcome these obstacles. Fifth, reflect critically from those four points. The results showed that kompas.com put FPI as the wrong position and the government's decision to dissolve FPI through an SKB was right. It is clear that kompas.com sided with the government. Kompas.com follows part of the flow of public votes in its news about FPI as a business strategy. The positioning of kompas.com was carried out because the government's decision to dissolve FPI caused pro and contra among the media and the public.
\end{abstract}

Keywords: news, construction, Norman Fairclough's Critical Discourse Analysis, FPI

\begin{abstract}
ABSTRAK
Keputusan pemerintah terkait pembubaran dan pemberhentian seluruh kegiatan Front Pembela Islam (FPI) memunculkan pro dan kontra di kalangan media dan masyarakat. Pembubaran FPI diputuskan melalui SKB yang ditandatangani enam menteri dan kepala lembaga negara. Penelitian ini bertujuan untuk mendeskripsikan dan membongkar wacana teks berita keputusan pembubaran FPI dengan menggunakan Analisis Wacana Kritis. Metode penelitian yang digunakan adalah Analisis Wacana Kritis Norman Fairclough melalui pemahaman teks dan konteks. Ada lima langkah yang dijadikan acuan. Pertama, fokus kepada ketidakberesan sosial dalam aspek semiotikanya. Kedua, mengidentifikasi hambatan-hambatan untuk menangani aspek ketidakberesan sosial tersebut. Ketiga, mempertimbangkan apakah tatanan sosial membutuhkan ketidakberesan sosial itu. Keempat, mengidentifikasi cara-cara yang mungkin untuk mengatasi hambatan tersebut. Kelima, melakukan refleksi secara kritis dari keempat poin tersebut. Hasil penelitian menunjukkan bahwa kompas.com meletakkan FPI sebagai pihak yang salah dan keputusan pemerintah membubarkan FPI melalui SKB sebagai keputusan yang benar. Terlihat jelas keberpihakan kompas.com pada pemerintah. Pihak kompas.com mengikuti sebagian arus suara publik dalam pemberitaannya tentang FPI sebagai strategi bisnis. Positioning kompas.com dilakukan karena keputusan pemerintah membubarkan FPI menimbulkan pro dan kontra di kalangan media maupun masyarakat.
\end{abstract}


Kata Kunci : Berita, Konstruksi, Wacana Kritis Norman Fairclough, FPI

\section{Latar Belakang}

Front Pembela Islam (FPI) adalah sebuah nama organisasi kemasyarakatan yang tidak asing lagi. Organisasi ini dengan cepat popular di Indonesia sejak beberapa tahun belakangan. FPI sering muncul di berbagai media massa dalam pemberitaan yang kontroversial dan selalu menyedot perhatian masyarakat. Ini berhubungan erat dengan kegiatan utama FPI yaitu melakukan aksi-aksi "penertiban" (sweeping) dan seringkali berujung pada kekerasan (Syaefuddin, 2014). Bisa dikatakan aktivitas utama FPI adalah merazia tempat hiburan yang mereka anggap sebagai sarang kemaksiatan seperti klub malam, diskotik, kafe, kasino, dll. (Jamhari, 2004)

FPI mulai terkenal pasca reformasi di Indonesia. Gerakannya sering diwujudkan dalam tindakan radikal yang menimbulkan rasa takut dan bahkan menjadi momok bagi sebagian masyarakat. FPI juga adalah salah satu kelompok Islam fundamentalis. Jargon yang mereka gunakan tidak jauh dari doktrin menegakkan hukum Allah, lebih khusus lagi pengenaan hukum Islam, dan penolakan mereka terhadap Barat (Jamhari, 2004).

Beragam kasus hukum yang melibatkan Front Pembela Islam (FPI) akhirnya berujung pada dikeluarkannya keputusan pembubaran organisasi itu oleh pemerintah. Pembubaran FPI diputuskan lewat surat keputusan bersama (SKB) yang ditandatangani enam pejabat menteri dan kepala lembaga negara. Mereka yang menandatangani SKB adalah Menteri Dalam Negeri Tito Karnavian, Menteri Hukum dan HAM Yasonna Laoly, Menteri Komunikasi dan Informatika Johnny $G$ Plate, Jaksa Agung ST Burhanuddin, Kepala BNPT Boy Rafli Amar dan Kapolri
Jenderal Idham Azis (cnnindonesia.com, 2020).

Keenamnya menuangkan dalam
Surat Keputusan Bersama Nomor 220/4780 Tahun 2020, Nomor M.HH/14.HH05.05 Tahun 2020, Nomor 690 Tahun 2020, Nomor 264 Tahun 2020, Nomor KB/3/XXI Tahun 2020, dan Nomor 320 Tahun 2020 tentang Larangan Kegiatan Penggunaan Simbol dan Atribut Serta Penghentian Kegiatan FPI. Isi SKB ini berlaku mulai 30 Desember 2020 dan telah dibacakan dihadapan media oleh Wakil Menteri Hukum dan HAM Eddy Hiariej (kompas.com, 2020). Dengan demikian, keberadaan FPI yang tersebar di Indonesia tidak diakui lagi. Bahkan seluruh kegiatan yang dilakukan FPI pasca dikeluarkannya SKB tersebut bisa dibubarkan polisi

Semenjak dibentuk pada tahun 1998, FPI sudah sering melakukan aksiaksi anarkis yang meresahkan masyarakat. Aksi FPI sering juga berujung konflik dengan masyarakat, karena masyarakat mengganggap bahwa tidak ada surat izin yang dikeluarkan oleh pihak kepolisian terhadap aksi-aksi seperti sweeping yang dilakukan oleh FPI. Sebagian menganggap FPI telah melewati batas kewenangannya yang seharusnya menjadi fungsi penegak hukum (kepolisian) bila merujuk pada Undang-Undang Nomor 2 Tahun 2002 tentang Kepolisian Negara RI.

Pada tingkat ekstrim, FPI menganggap nilai-nilai yang dianutnya adalah benar. Bahkan, secara terangterangan mereka melakukan perlawanan terhadap nilai dan norma yang bertentangan dengan apa yang mereka yakini. Yang membuat FPI menjadi radikal adalah ketika cita-cita bagi terlaksananya kehidupan menurut keyakinan mereka tersebut ditempuh dengan menggunakan kekerasan dan cara-cara yang drastis. 
Kekerasan dan cara-cara drastis itu kadang-kadang menimbulkan ketakutan pada diri banyak orang serta dapat pula mengganggu stabilitas negara (Damayanti, dkk., 2003)

Menurut laporan Wahid Institute(2013), FPI memiliki rekam jejak kekerasanyang cukup panjang. Ada Peristiwa Monas,ada peristiwa-peristiwa kekerasan terhadap kelompok Ahmadiyah. Mereka tak lelah menuntut pembubaran Ahmadiyah yang dipandang sebagai umat yang sudah keluar dari Islam, bahkan FPI pernah mengancam akan melakukan revolusi jika Presiden Susilo Bambang Yudoyono (SBY) tak kunjung membubarkan kelompok Ahmadiyah. FPI sering melakukan demonstrasi dengan pengerahan massa pendukung yang besar hingga pernah merusak kantor Kemendagri (Kementerian dalam Negeri) untuk menuntut tidak dicabutnya perda anti-miras di sembilan daerah di Indonesia.

Namun demikian, secara obyektif harus disebutkan pula bahwa disamping aksi-aksi kontroversial yang kerap mereka lakukan, FPI juga banyak melibatkan diri dalam aksi-aksi kemanusiaan antara lain pengiriman relawan ke daerah bencana tsunami di Aceh, bantuan relawan dan logistik saat bencana gempa di Padang dan beberapa aktivitas kemanusiaan lainnya (Faiz, 2014)

FPI secara resmi berdiri pada tanggal 17 Agustus 1998, bertepatan dengan tanggal 24 Rabiuts Tsani $1419 \mathrm{H}$, di pondok pesantren Alum Kampong Utan, Ciputat, Jakarta Selatan. FPI didirikan oleh sejumlah haba'ib, ulama', muballigh, serta aktivis muslim dan umat Islam. Tokoh yang mempelopori berdirinya FPI adalah Muhammad Rizieq Shihab. Tidak hanya di Jakarta, seiring berjalannya waktu, simpatisan FPI bertambah banyak dan mendirikan FPI di daerah-daerah, Seperti di Surakarta, Bandung dan Yogyakarta hingga hampir di setiap kota di Indonesia (Jamhari, 2004).

Dan wacana keputusan pemerintah terkait pembubaran dan pemberhentian seluruh kegiatan FPI yang mulai berlaku pada tanggal 30 Desember 2020 lalu memunculkan pro dan kontra yang masih bergulir dan terus menjadi pembicaraan hangat media maupun masyarakat di negeri ini. Mereka yang mengikuti sepak terjang FPI ramai mengemukakan pendapatnya. Bahkan Kompas.com edisi 31 Desember 2021 memberitakan adanya puluhan karangan bunga yang tersebar di sejumlah lokasi di Surabaya yang berisikan ucapan terima kasih kepada pemerintah karena telah membubarkan FPI.

Sejatinya suatu berita patut diangkat selain karena mengandung unsur news value, salah satu yang dianggap penting adalah jika kekuasaan politik dan kekuasaan media bersatu atau bersinergis (Iskandar dan Rini, 2016). Sedang kalangan kritis beranggapan bahwa berita bukanlah sekedar subyektivitas dari si pembuat berita, melainkan ada suatu kekuatan dominan yang mempengaruhi konstruksinya. Ternyata media bukanlah entitas yang netral, tetapi bisa dikuasai oleh kelompok dominan (Eriyanto, 2012). Oleh karena itu, penulis tertarik untuk menganalisis teks berita keputusan pembubaran FPI yang belakangan ini ramai diberitakan oleh portal berita online.

Tayangan, tulisan, dan siaran yang dikemas dalam bentuk berita dan menjadi perbincangan hangat di masyarakat disebut wacana (discourse). Semakin besar wacana yang dihasilkan melalui media, kian peluang memproduksi makna untuk khalayak. Banyak cara yang dilakukan media dalam memproduksi wacana 
(Hamad, 2010). Berbeda dengan Piliang (2011) yang mendefinisikan wacana (discourse) sebagai kesatuan yang utuh antara teks, konteks, dan praktik sosial. Wacana merupakan cara menghasilkan pengetahuan dan praktik sosialnya, bentuk subjektivitas yang terbentuk darinya, relasi kekuasaan di balik pengetahuan dan praktik sosial tersebut serta kesalingberkaitan di antara semuanya.

Istilah wacana sesungguhnya tidak berdiri sendiri. la berkelindan dengan istilah khas lainnya milik Foucault seperti episteme, arkeologi, dan genealogi. Di mana secara historis Michel Foucault (1978, 1979) yang sesungguhnya menjadi konseptor awal istilah wacana. Dari sinilah muncul teori relasi pengetahuan dan kekuasaan atau kekuasaan dan pengetahuan (power/knowledge atau pouvoir/savoir). Pengetahuan/kekuasaan berkerja melalui bahasa (Lubis, 2014).

Berangkat dari penjelasan di atas, maka penelitian ini bertujuan untuk mendeskripsikan dan membongkar wacana dalam teks berita keputusan pembubaran FPI dengan menggunakan Analisis Wacana Kritis (AWK). Pendekatan kritis terhadap teks media bertujuan membongkar maksud tersembunyi dalam satu berita, misalnya. Pendekatan kritis tidak semata-mata melihat teks sebagai obyek studi bahasa. la dipandang sebagai alat dan praktik kekuasaan.

Menurut Haryatmoko (2016), AWK mencoba untuk membongkar yang salah atau tidak beres di masyarakat, seperti adanya ketidakadilan, ketaksetaraan, pembatasan kebebasan atau diskriminasi. Agar AWK semakin tajam, orang perlu menganalisis pula hubungan dengan luar teks yang meliputi. Analisis ini membahas bagaimana unsur lain secara intertekstual terkait dengan teks; dan bagaimana suarasuara lain termuat dalam teks; akhirnya, bagaimana teks lain disinggung, diasumsikan, atau didialogkan. Intertekstualitas ini bisa tampak dalam dua bentuk: pertama, kehadiran unsurunsur dari teks lain dalam suatu teks yang bisa berupa kutipan, acuan, atau isi; kedua, dalam laporan pembicaraan, tulisan atau pikiran, bukan hanya kutipan yang kita jumpai, namun bisa juga ringkasan. Maka teks selalu memiliki asumsi.

Di sini penulis fokus pada teks berita yang diproduksi oleh kompas.com dengan beberapa alasan. Pertama, kompas.com merupakan salah satu portal berita yang paling banyak memproduksi berita tentang keputusan pembubaran FPI terutama sejak diberlakukan SKB yang ditandatangani enam menteri/kepala lembaga pada tanggal 30 Desember 2020. Kedua, kompas.com merupakan salah satu portal berita yang populer dibaca khalayak dengan jumlah user mencapai 30.000 per harinya. Ketiga, kompas.com merupakan media dengan ideologi nasionalis dan berada di bawah naungan Kompas Gramedia.

\section{Metode}

Metode yang digunakan dalam penelitian ini adalah Analisis Wacana Kritis Model Norman Fairclough yang didasarkan pada sebuah pertanyaan: bagaimana menghubungkan teks yang mikro dengan konteks masyarakat yang makro. Analisis Wacana Kritis Model Norman Fairclough harus dipusatkan pada bagaimana bahasa itu terbentuk dan dibentuk dari relasi sosial dan konteks sosial tertentu. Titik utamanya adalah melihat bahasa sebagai praktik kekuasaan.

Fairclough (2010) menawarkan empat langkah metode AWK. Pertama, memfokuskan pada suatu 'ketidakberesan sosial', dalam aspek semiotiknya. Kedua, mengidentifikasi hambatan-hambatan untuk menangani 'ketidakberesan sosial' 
itu. Ketiga, mempertimbangkan apakah tatanan sosial itu 'membutuhkan' ketidakberesan sosial tersebut. Keempat, mengidentifikasi cara-cara yang mungkin untuk mengatasi hambatan-hambatan itu.

Faiclough melihat teks dalam berbagai tingkatan. Sebuah teks bukan hanya menampilkan bagaimana suatu obyek digambarkan tetapi juga bagaimana hubungan antarobyek didefinisikan. Ada tiga elemen dasar dalam Model Fairclough, yang dapat digambarkan ke dalam tabel berikut (Eriyanto, 2001).

Tabel 1

Analisis Teks

\begin{tabular}{|c|l|}
\hline UNSUR & \multicolumn{1}{|c|}{\begin{tabular}{c}
\multicolumn{1}{|c|}{ YANG INGIN } \\
DILIH
\end{tabular}} \\
\hline Representasi & $\begin{array}{l}\text { Representasi } \\
\text { bagaimana peristiwa, } \\
\text { orang, kelompok, } \\
\text { situasi, keadaan, atau } \\
\text { apapun ditampilkan } \\
\text { dan digambarkan } \\
\text { dalam teks. }\end{array}$ \\
\hline Relasi & $\begin{array}{l}\text { Bagaimana hubungan } \\
\text { antara wartawan, } \\
\text { khalayak, dan } \\
\text { partisipan berita } \\
\text { ditampilkan dan } \\
\text { digambarkan dalam } \\
\text { teks. }\end{array}$ \\
\hline Identitas & $\begin{array}{l}\text { Bagaimana identitas } \\
\text { wartawan, khalayak, } \\
\text { dan partisipan berita } \\
\text { ditampilkan dan } \\
\text { digambarkan dalam } \\
\text { teks. }\end{array}$ \\
\hline
\end{tabular}

Sumber : Model Norman Fairclough

(Eriyanto, 2001)

Adapun objek penelitian ini adalah empat teks berita tentang keputusan pembubaran FPI di kompas.com edisi 30 Desember 2020. Berita yang dimaksud terdapat dalam tabel di bawah ini:

Tabel 2

Objek Penelitian

\begin{tabular}{|c|c|c|c|}
\hline Media & $\begin{array}{c}\text { Dat } \\
\text { a }\end{array}$ & $\begin{array}{c}\text { Judul } \\
\text { Berita }\end{array}$ & Waktu \\
\hline
\end{tabular}

\begin{tabular}{|c|c|c|c|}
\hline \multirow[t]{3}{*}{$\begin{array}{c}\text { Kompas.c } \\
\text { om }\end{array}$} & 1 & $\begin{array}{l}\text { Breaking } \\
\text { News: } \\
\text { Pemerint } \\
\text { ah } \\
\text { Bubarkan } \\
\text { dan } \\
\text { Hentikan } \\
\text { Kegiatan } \\
\text { FPI }\end{array}$ & $\begin{array}{l}30 \\
\text { Desem } \\
\text { ber } \\
2020 ; \\
12: 28 \\
\text { WIB }\end{array}$ \\
\hline & 2 & $\begin{array}{l}\text { Pembuba } \\
\text { ran dan } \\
\text { Penghent } \\
\text { ian } \\
\text { Aktivitas } \\
\text { FPI } \\
\text { Diputus } 6 \\
\text { Pejabat } \\
\text { Tinggi } \\
\text { Negara }\end{array}$ & $\begin{array}{l}30 \\
\text { Desem } \\
\text { ber } \\
2020 ; \\
12: 52 \\
\text { WIB }\end{array}$ \\
\hline & 3 & $\begin{array}{l}\text { FPI Resmi } \\
\text { Dibubark } \\
\text { an, } \\
\text { Pengguna } \\
\text { an Simbol } \\
\text { hingga } \\
\text { Atribut } \\
\text { Dilarang }\end{array}$ & $\begin{array}{l}30 \\
\text { Desemb } \\
\text { er 2020; } \\
\text { 13:53 } \\
\text { WIB }\end{array}$ \\
\hline & 4 & $\begin{array}{l}\text { FPI } \\
\text { Dibubarkan } \\
\text {, Karangan } \\
\text { Bunga } \\
\text { Ucapan } \\
\text { Terima } \\
\text { Kasih } \\
\text { Tersebar di } \\
\text { Surabaya }\end{array}$ & $\begin{array}{l}30 \\
\text { Desembe } \\
\text { r 2020; } \\
21: 28 \\
\text { WIB }\end{array}$ \\
\hline
\end{tabular}

Sumber : data penelitian, 2021

\section{Pembahasan}

Pekerjaan media massa adalah menceritakan kembali peristiwa-peristiwa, maka kesibukan utama media massa adalah mengkonstruksi berbagai realitas yang akan disiarkan. Media menyusun realitas dari berbagai peristiwa yang terjadi hingga menjadi cerita atau wacana yang bermakna (Hamad, 2004). Dengan demikian seluruh isi media tiada lain adalah realitas yang telah dikonstruksikan (constructed reality) dalam bentuk wacana yang bermakna. Dalam proses konstruksi realitas, bahasa adalah unsur utama. 
Bahasa adalah alat konseptualisasi dan alat narasi. Selanjutnya, penggunaan bahasa (simbol) tertentu menentukan format narasi (dan makna) tertentu (Hamad, 2014).

Faktor-faktor yang mempengaruhi proses konstruksi realitas media terhadap suatu peristiwa secara umum berasal dari sistem komunikasi yang berlaku. Dalam sistem komunikasi, dinamika internal dan eksternal pelaku konstruksi serta strategi dalam mengkonstruksi realitas akan mempengaruhi wacana yang dihasilkan. Proses konstruksi realitas tersebut pada awalnya politik, namun akhirnya juga digunakan untuk menganalisis wacanawacana lain dalam berbagai bentuk mediasi komunikasi (Hamad, 2010)

Dalam suatu konstruksi pemberitaan di media massa, proses produksi berita tidak dapat terlepas dari adanya hegemoni bahasa. Bahasa yang semula digunakan sebagai alat komunikasi sudah bergeser menjadi alat untuk berpolitik, budaya, dan alat untuk mendapatkan kekuasaan. Kini, bahasa dalam suatu wacana dijadikan suatu pembenaran tentang bagaimana suatu pihak mampu menguasai orang lain untuk diperdaya dan menguasai lawannya dengan menggunakan kekuatan bahasa (Mardikantoro, dkk. 2019).

\section{'Ketidakberesan Sosial' dalam Aspek Semiotik}

Ketidakberesan sosial dipahami sebagai aspek-aspek sistem sosial, bentuk dan tatanan yang merugikan atau merusak kesejahteraan bersama, yang bisa diperbaiki meski harus melalui perubahanperubahan radikal dari sistem. Ketidakberesan sosial itu meliputi kemiskinan, ketidasetaraan, diskriminasi, kurangnya kebebasan atau rasisme (Haryatmoko, 2016).
Inti dari analisis wacana kritis Norman Fairclough (1995) adalah ingin melihat bahasa sebagai praktik kekuasaan. Sebuah kekuasaan tidak mungkin hadir tanpa ideologi. Ideologi, kata Fairclough (1995), adalah makna yang melayani kekuasaan. Meminjam istilah Michel Foucault, dalam bahasa ada selalu hadir kekuasaan. Berarti analisis bahasa adalah untuk membongkar representasi kekuasaan yang ada di media.

Dari empat berita yang dijadikan basis wacana dan dianalisis, semua menunjukkan satu hal bahwa kompas.com meletakkan FPI sebagai pihak yang salah dan keputusan pemerintah membubarkan FPI melalui SKB enam menteri dan kepala lembaga negara sebagai keputusan yang benar. Terlihat jelas pada perbendaharaan kata dan penggunaan istilah sudah menyiratkan keberpihakan kompas.com pada pemerintah.

a. Kompas.com beberapa kali menggunakan pilihan diksi seperti "membubarkan", "bubarkan", "pembubaran", "menghentikan", "hentikan", "menolak", "disetujui", dan "melarang". Pilihan diksi tersebut menggambarkan bahwa pemerintah benar-benar serius dan telah bertindak tegas terhadap FPI di penghujung tahun 2020. Pemerintah punya alasan melakukan itu. Kompas.com menggunakan pilihan diksi seperti "pelanggaran" dan "terlarang" untuk menggambarkan FPI sebagai pihak yang salah. Singkat kata, keputusan pembubaran FPI melalui SKB enam menteri dan kepala lembaga negara adalah keputusan benar karena sifatnya berkekuatan hukum berdasarkan pertimbangan adanya pelanggaran-pelanggaran hukum yang dilakukan oleh FPI selama ini. 
b. Kompas.com menggunakan istilah seperti "de jure", 'legal standing sebagai ormas", "ideologi Pancasila", "keputusan bersama", dan "menjaga kemaslahatan" memberi kesan bahwa keputusan pembubaran FPI melalui SKB enam menteri dan kepala lembaga negara tertanggal 30 Desember 2020 sudah berjalan secara adil dan sudah sesuai aturan serta peraturan perundangundangan yang berlaku.

c. Kompas.com menegaskan dalam kalimat panjang. "Bahwa untuk menjaga eksitensi ideologi dan konsensus dasar bernegara yaitu Pancasila, UUD 1945, keutuhan NKRI, dan Bhinekka Tunggal Ika". Argumentasi ini untuk menjelaskan salah satu pertimbangan utama pemerintah membubarkan FPI. Sebab apa yang dilakukan FPI selama ini sudah tidak sejalan dengan ideologi dan nilai-nilai yang diyakini dan dianut masyarakat Indonesia sejak menyatakan diri sebagai negara merdeka dan berdaulat.

Pelanggaranpelanggaran FPI dituangkan secara jelas dalam SKB enam menteri dan kepala lembaga negara. Dan kompas.com membeberkan isi dari SKB tersebut dalam beberapa beritanya.

Pertanyaannya adalah ada apa di balik berita kompas.com yang setuju diberlakukannya SKB enam menteri dan kepala lembaga negara tentang pembubaran dan pemberhentian seluruh kegiatan FPI? Ada apa di balik berita kompas.com yang menyalahkan dan menyudutkan FPI? Lebih jelasnya lihat tabel di bawah ini :
Tabel 3

Konstruksi Wacana

\begin{tabular}{|c|c|c|}
\hline \multicolumn{2}{|r|}{ Nama Media } & Kompas.com \\
\hline & Edisi & 30 Desember 2020 \\
\hline & Wacana & $\begin{array}{l}\text { Keputusan } \\
\text { Pembubaran FPI dan } \\
\text { Konstruksi Berita } \\
\text { Kompas.com }\end{array}$ \\
\hline \multicolumn{3}{|c|}{ Konstruksi Wacana } \\
\hline No. & Unsur & Keterangan \\
\hline 1. & $\begin{array}{l}\text { Kosa Kata } \\
\text { Kalimat } \\
\text { Istilah }\end{array}$ & $\begin{array}{l}\text { Ormas terlarang, } \\
\text { tidak terdaftar, } \\
\text { resmi dilarang, } \\
\text { mendukung } \\
\text { pemerintah, } \\
\text { membubarkan, } \\
\text { menghentikan, } \\
\text { pembubaran, } \\
\text { menghentikan, } \\
\text { peraturan } \\
\text { perundang- } \\
\text { undangan, } \\
\text { keputusan bersama, } \\
\text { bertentangan } \\
\text { dengan hukum, } \\
\text { ideologi Pancasila }\end{array}$ \\
\hline 2. & Metafora & $\begin{array}{l}\text { Menjaga } \\
\text { kemaslahatan, legal } \\
\text { standing sebagai } \\
\text { ormas, de jure }\end{array}$ \\
\hline 3. & $\begin{array}{l}\text { Struktur teks } \\
\text { yang } \\
\text { mengungkap } \\
\text { logika } \\
\text { argumentasi }\end{array}$ & $\begin{array}{l}\text { Dari awal hingga } \\
\text { akhir membangun } \\
\text { susunan logika yang } \\
\text { menyudutkan FPI. } \\
\text { FPI tidak memiliki } \\
\text { legal standing. FPI } \\
\text { terus melakukan } \\
\text { kegiatan yang } \\
\text { mengganggu } \\
\text { ketentraman, } \\
\text { ketertiban umum, } \\
\text { dan bertentangan } \\
\text { dengan hukum. } \\
\text { Pembubaran dan } \\
\text { penghentian } \\
\text { aktivitas FPI sudah } \\
\text { sesuai peraturan } \\
\text { perundang- } \\
\text { undangan yang } \\
\text { berlaku. } \\
\text { Sangat jelas FPI } \\
\text { sebagai pihak yang } \\
\text { salah dan keputusan }\end{array}$ \\
\hline
\end{tabular}




\begin{tabular}{|c|c|c|}
\hline & & $\begin{array}{l}\text { pembubaran FPI } \\
\text { oleh pemerintah } \\
\text { sebagai keputusan } \\
\text { yang benar dan } \\
\text { tepat. }\end{array}$ \\
\hline 4. & $\begin{array}{c}\text { Tata Bahasa dan } \\
\text { Kohes }\end{array}$ & $\begin{array}{l}\text { Pemilihan diksi, } \\
\text { kalimat, metafora, } \\
\text { dan lain-lain yang } \\
\text { dipakai dan } \\
\text { pemaknaan kata } \\
\text { cenderung memberi } \\
\text { gambaran yang } \\
\text { merugikan FPI, } \\
\text { namun } \\
\text { menguntungkan } \\
\text { pihak pemerintah. } \\
\text { Hampir tak ada } \\
\text { deskripsi hal-hal } \\
\text { yang } \\
\text { menguntungkan FPI. } \\
\text { Deskripsi yang berat } \\
\text { sebelah ini tampak } \\
\text { semakin mencolok } \\
\text { dan mencitrakan FPI } \\
\text { negatif. }\end{array}$ \\
\hline
\end{tabular}

Sumber : hasil penelitian tahun 2021

Terlihat tabel di atas bagaimana redaksi kompas.com meletakkan dan mengkonstruksi pembubaran FPI. Penggunaan metafora seperti menjaga kemaslahatan, "de jure", dan legal standing menunjukan FPI sedang dibidik oleh kompas.com. Posisi kompas.com yang sejalan dengan arus utama suara publik menunjukkan satu hal bahwa kompas.com sedang mencari positioning dalam ranah pertarungan antarmedia online yang kian sengit setiap saat. Karena tidak semua media dan elemen masyarakat yang setuju dengan pemberlakuan SKB enam menteri dan kepala lembaga negara. Mereka yang mengaku pro-demokrasi dan proreformasi tidak mendukung tindakan pemerintah membubarkan FPI, sebab pembubaran FPI bertentangan dengan nilai-nilai demokrasi dan juga nilai-nilai reformasi.

\section{Beberapa tokoh ormas Islam} bahkan berani mengkritik langkah pemerintah yang melarang aktivitas FPI dan membubarkan ormas tersebut melalui pemberitaan media. Menurut mereka, ini sama halnya dengan mencederai demokrasi di Indonesia. Lebih dari itu tidak sejalan dengan nilai-nilai reformasi yang memberi kebebasan berserikat dan berkumpul tanpa ada lagi intervensi dari pemerintah maupun penguasa.

Tidak sedikit pula yang menyebutkan bahwa terbitnya SKB enam menteri dan kepala lembaga negara hanyalah sebagai langkah politik yang dilakukan oleh pemerintah (dalam hal ini pemerintahan Jokowi) agar FPI tak lagi melakukan hal-hal yang dapat membahayakan kekuasaan. Apalagi dalam surat tersebut pemerintah menyimpulkan bahwa organisasi yang dipimpin Rizieq Shihab itu berafiliasi dengan terorisme, tanpa melewati proses hukum yang jelas. Meski hal ini dibantah oleh beberapa kalangan yang menganggap dugaan pemerintah tersebut sangatlah berlebihan.

\section{Mengidentifikasi Hambatan untuk Menangani 'Ketidakberesan Sosial'}

Pada tahap ini, pendekatan terhadap ketidakberesan sosial ditempuh dengan cara tidak langsung, yaitu dengan menanyakan cara bagaimana kehidupan sosial diorganisir dan distruktur sehingga mencegahnya dari upaya menanganinya. Hal ini butuh analisis tatanan sosial dan satu titik masuk ke analisis menjadi semiotik. Maka perlu menyeleksi dan menganalisis teks-teks yang relevan dan membahas hubungan dialektik antara semiosis dan unsur-unsur sosial lainnya (Haryatmoko, 2016).

Dari empat berita yang dijadikan basis wacana dan dianalisis, semua menunjukkan bahwa kompas.com 
menempatkan FPI sebagai organisasi yang tidak memiliki legal standing sebagai organisasi kemasyarakatan. Selain itu, pemerintah menyebut FPI selama ini melakukan pelanggaran-pelanggaran yang bertentangan dengan hukum. Kompas.com beberapa kali dalam beritanya mengutip pernyataan Wakil Menteri Hukum dan HAM Eddy Hiariej bahwa pembubaran FPI bertujuan untuk menjaga eksitensi ideologi dan konsensus dasar bernegara yaitu Pancasila, UUD 1945, keutuhan NKRI, dan Bhinekka Tunggal Ika.

Bahkan media menyebutkan sebanyak 35 orang laskar FPI disebut terlibat tindak pidana terorisme dan 29 orang di antaranya telah dijatuhi pidana. Di samping itu, 206 orang terlibat sebagai tindak pidana umum lainnya di mana 100 orang di antaranya dijatuhi hukuman pidana. Belum lagi isi anggaran dasar FPI bertentangan dengan pasal 2 UU 17/2014 tentang Organisasi Kemasyarakatan sebagaimana diubah dalam UU 16/2017 tentang penetapan Peraturan Pemerintah Pengganti Undang-Undang 2/2017 (cnbcindonesia.com, 2020).

Atas dasar itu, pemerintah memutuskan untuk membubarkan FPI dan melarang segala aktivitas yang dilakukannya. Pembubaran itu dituangkan dalam SKB Menteri Dalam Negeri, Menteri Hukum dan HAM, Menteri Komunikasi dan Informatika, Jaksa Agung, Kapolri, serta Kepala Badan Nasional Penanggulangan Terorisme (BNPT). Isi SKB yang berlaku mulai 30 Desember 2020 itu dibacakan oleh Wakil Menteri Hukum dan HAM Eddy Hiariej.

Berdasarkan SKB, pemerintah menyebutkan :

1) Front Pembela Islam adalah organisasi yang tidak terdaftar sebagai organisasi kemasyarakatan, sebagaimana diatur dalam peraturan perundang-undangan sehingga secara de jure telah bubar sebagai organisasi kemasyarakatan.

2) Front Pembela Islam sebagai organisasi kemasyarakatan yang secara de jure telah bubar pada kenyataannya masih terus melakukan kegiatan yang mengganggu ketentraman, ketertiban umum, dan bertentangan dengan hukum.

3) Melarang dilakukannya kegiatan, penggunaan simbol dan atribut Front Pembela Islam dalam wilayah hukum Republik Indonesia.

4) Apabila terjadi pelanggaran sebagaimana diatur dalam diktum ketiga di atas, aparat penegak hukum akan menghentikan semua kegiatan yang diselenggarakan Front Pembela Islam.

5) Meminta kepada masyarakat:

a. Untuk tidak terpengaruh, terlibat dalam kegiatan, penggunaan simbol dan atribut Front Pembela Islam.

b. Untuk melaporkan kepada aparat penegak hukum setiap kegiatan penggunaan simbol dan atribut Front Pembela Islam.

6) Kementerian/lembaga yang menandatangani Surat Keputusan Bersama ini agar melakukan koordinasi dan mengambil langkahlangkah hukum sesuai ketentuan perundang-undangan.

7) Keputusan Bersama ini mulai berlaku ditetapkan (kompas.com. 2020).

Ketegasan pemerintah terhadap Rizieq Shihab dan pembubaran FPI turut mendongkrak kepuasan publik terhadap Jokowi. Survei Voxpopuli Research Center dilakukan pada 26-31 Desember 2020, melalui sambungan telepon kepada 1.200 responden di seluruh 
Indonesia yang dipilih secara acak dari survei sebelumnya sejak 2019. Hasil survei yang dilakukan Voxpopuli Research Center menunjukkan tingkat kepuasan publik terhadap Presiden Jokowi mengalami kenaikan. Pada momentum satu tahun periode kedua bulan Oktober 2020, tingkat kepuasan terhadap Jokowi mencapai 64,7 persen. Angkanya kini naik menyentuh 70 persen, tepatnya 72,8 persen. Sedangkan, angka ketidakpuasan turun dari 30,6 persen menjadi 23,3 persen. Sisanya menyatakan tidak tahu/tidak menjawab (4,7 persen-3,9 persen) (liputan6.com, 2021).

Survei lain juga menunjukkan dukungan publik terkait tindakan tegas pada anggota FPI yang melanggar. Survei Polmatrix Indonesia menunjukkan mayoritas publik mendukung sikap Polri menindak anggota FPI yang dinilai melanggar hukum. Survei Polmatrix Indonesia dilakukan pada 20-25 Desember 2020 kepada 2.000 orang responden mewakili 34 provinsi. Dukungan terhadap Polri menindak tegas Rizieq Shihab dan oknum FPI mencapai 82,9 persen. Hanya sebagian kecil yang tidak setuju terhadap tindakan tegas polisi ( 11,3 persen), dan sisanya menyatakan tidak tahu/tidak menjawab (5,8 persen) (antaranews.com, 2020).

\section{Mengidentifikasi Apakah Tatanan Sosial 'Membutuhkan' Ketidakberesan Sosial}

Apakah 'ketidakberesan sosial' melekat pada tatanan sosial, apakah dapat ditangani dalam sistem tersebut, atau hanya bisa ditangani bila diubah. Ini adalah cara menghubungkan antara 'yang faktual' dan 'yang seharusnya': jika suatu tatanan sosial dapat ditunjukkan untuk menghasilkan 'ketidakberesan sosial' yang besar, maka menjadi alasan untuk memikirkan agar diubahnya. Hal ini terkait dengan masalah ideologi: wacana selalu ideologis sejauh menyumbang untuk mendukung hubungan kekuasaan dan dominasi tertentu (Haryatmoko, 2016).

Kalau diamati secara lebih dekat mengapa SKB Pembubaran FPI diberlakukan? Jawabannya jelas karena FPI telah melakukan sejumlah pelanggaran yang bertentangan dengan ideologi, hukum dan peraturan perundang-undangan yang berlaku. Selain itu, FPI diduga adalah bagian dari terorisme yang dapat menganggu keutuhan NKRI dan Bhinneka Tunggal Ika. Oleh karena itu, pemerintah mengambil langkah politik dan hukum dengan mengeluarkan SKB untuk membubarkan FPI. Keputusan SKB sejalan dengan putusan MK Nomor 82 PUU 11/2013 tertanggal 23 Desember 2014 tentang Undang-Undang Ormas.

Sebetulnya wacana pembubaran FPI sudah sejak lama dibicarakan oleh media. Bahkan sebagian masyarakat menuntut agar pemerintah mengambil tindakan tegas. Karena sebagian aktivitas FPI berupa sweeping dinilai meresahkan dan melampau batas kewenangan sebagai ormas. Pernyataan dalam artikel kompas.com yang dipilih redaksi seakanakan posisi pemerintah kuat dan posisi FPI lemah. Dengan penggunaan kata "membubarkan", "dibubarkan", "dihentikan", dan "menghentikan". Redaksi kompas.com tidak menggunakan penghalusan kata atau kalimat dalam artikelnya. Setidaknya ada argumentasi yang strukturnya menunjukkan betapa kuat dasar dikeluarkannya SKB enam menteri dan kepala lembaga negara terkait pembubaran FPI dan pelarangan segala aktivitas yang dilakukannya sejak diberlakukan pada tanggal 30 Desember 2020.

ketika diserang oleh sebagian
proreformasi bahwa keputusan 
pembubaran FPI melalui SKB adalah tindakan yang bertentangan dengan demokrasi dan reformasi, di sini kompas.com tampil membela pemerintah dalam pemberitaannya khusus pada edisi 30 Desember 2020. Ini terlihat dari keseluruhan berita yang diproduksi pada hari diumumkannya pemberlakukan SKB. Bahkan kompas.com sempat mengutip pernyataan dalam pemberitaannya bahwa FPI disebut-sebut sebagai bagian dari terorisme.

Keberpihakan kompas.com selain kelihatan dari struktur argumentasi, juga tampak di dalam absennya suara FPI dalam semua berita yang tayang pada 30 Desember 2020. Tak ada satu pun dari pihak FPI yang dijadikan sumber berita terkait sikap dan keberatan mereka dengan ditetapkannya SKB enam menteri dan kepala lembaga negara sebagai dasar hukum pembubaran FPI dan pelarangan segala aktivitas yang dilakukannya. FPI sebagai pihak yang bersalah dan keputusan pemerintah membubarkan FPI adalah yang benar.

Di sinilah pencitraan pemerintah sebagai pihak yang dibela kompas.com. pemerintah berhasil membangun opini publik yang positif bahwa mereka bisa bersikap tegas kepada FPI yang selama ini dianggap sebagai ormas yang ditakuti, ormas yang sebagian besar aktivitasnya identik dengan kekerasan dan pengrusakan, ormas yang sangat berani menentang apa yang tidak sesuai dengan apa yang mereka yakini.

Dengan demikian, citra politik sesungguhnya memiliki makna meski tidak menggambarkan sesuatu yang sebenarnya. Dengan demikian sesungguhnya pencitraan bukan gambaran sejati dari yang dicitrakan. Apalagi pencitraan yang dihasilkan oleh media massa. Sebab berita yang diterima dan mempengaruhi khalayak bukan realitas yang sebenarnya. la menjadi realitas buatan atau realitas kedua atau realitas buatan (Suryawati dan Agustiar, 2018).

\section{Mengidentifikasi Cara yang Mungkin untuk Mengatasi Hambatan}

Analisis pada tahap ini mau mengidentifikasi kemungkinankemungkinan dalam proses sosial yang ada untuk mengatasi hambatan-hambatan menangani 'ketidakberesan sosial'. (Haryatmoko, 2016). Keputusan pembubaran FPI ini disetujui oleh enam pejabat tinggi di kementerian maupun lembaga negara. Melarang dilakukannya kegiatan, penggunaan simbol dan atribut FPI dalam wilayah hukum Republik Indonesia. Keputusan pemerintah ini sudah sesuai aturan dan perundangundangan yang berlaku. Salah satunya adalah putusan Mahkamah Konstitusi terkait Undang-Undang Ormas.

Kalau melihat paparan argument empat berita yang menjadi objek penelitian menunjukkan pemerintah telah mengambil sikap dan langkah tegas terhadap keberadaan FPI. Ada jalan keluar untuk mengatasi ketidakberesan sosial lewat SKB yang ditandatangani enam menteri dan kepala lembaga negara pada tanggal 30 Desember 2020. Apa yang tak pernah dipikirkan bahwa pemerintah bisa tegas terhadap FPI menjadi sesuatu yang nyata. Alasan utama yang mendasari tindakan pemerintah tersebut adalah tidak adanya legal standing terhadap ormas FPI, sehingga Menteri Koordinator Bidang Politik, Hukum, dan Keamanan Mahfud MD meminta pemerintah pusat dan daerah untuk menolak semua kegiatan yang dilakukan FPI.

Meski keputusan pembubaran FPI dianggap berlawanan dengan nilai-nilai 
demokrasi dan nilai-nilai reformasi yang menjadi prinsip bangsa Indonesia, pihak pemerintah tampaknya tak gentar akan hal tersebut. Pemerintah berdalih langkah pembubaran FPI bertujuan menjaga kepentingan bangsa dan negara yang lebih besar yaitu menjaga eksitensi ideologi dan konsensus dasar bernegara yaitu Pancasila, UUD 1945, keutuhan NKRI, dan Bhinekka Tunggal lka.

Tabel 4

Berita Keputusan Pembubaran FPI Dalam Konstruksi Kompas.com

Berdasarkan Element CDA Norman Fairclough

\begin{tabular}{|c|c|c|}
\hline No. & $\begin{array}{c}\text { Element CDA } \\
\text { Norman } \\
\text { Fairclough }\end{array}$ & Keterangan \\
\hline 1. & $\begin{array}{l}\text { Memfokuskan } \\
\text { pada } \\
\text { ketidakberesan } \\
\text { sosial dalam } \\
\text { aspek semiotika }\end{array}$ & $\begin{array}{l}\text { Pilihan kata, diksi, } \\
\text { kalimat dan judul } \\
\text { berita kompas.com } \\
\text { menunjukan posisi } \\
\text { media ini yang } \\
\text { mendukung } \\
\text { diterbitkannya SKB } \\
\text { pembubaran FPI } \\
\text { oleh pemerintah. } \\
\text { Dalam surat } \\
\text { keputusan tersebut } \\
\text { memuat alasan } \\
\text { pemerintah terkait } \\
\text { pembubaran } \\
\text { ormas yang } \\
\text { dipimpin Rizieq } \\
\text { Shihab. } \\
\text { Kompas.com } \\
\text { sejalan dengan } \\
\text { mayoritas suara } \\
\text { publik yang } \\
\text { menginginkan FPI } \\
\text { dibubarkan. }\end{array}$ \\
\hline 2. & $\begin{array}{l}\text { Identifikasi } \\
\text { hambatan- } \\
\text { hambatan untuk } \\
\text { menangani } \\
\text { ketidakberesan } \\
\text { sosial tersebut }\end{array}$ & $\begin{array}{l}\text { Kompas.com } \\
\text { menempatkan FPI } \\
\text { sebagai organisasi } \\
\text { yang tidak } \\
\text { memiliki legal } \\
\text { standing sebagai } \\
\text { organisasi } \\
\text { kemasyarakatan. } \\
\text { Kompas.com } \\
\text { berulangkali }\end{array}$ \\
\hline
\end{tabular}

\begin{tabular}{|c|c|c|}
\hline & & $\begin{array}{l}\text { menyebut FPI } \\
\text { selama ini } \\
\text { melakukan } \\
\text { pelanggaran- } \\
\text { pelanggaran yang } \\
\text { bertentangan } \\
\text { dengan hukum. } \\
\text { Keputusan } \\
\text { pemerintah } \\
\text { membubarkan FPI } \\
\text { memuaskan } \\
\text { sebagian besar } \\
\text { publik, meski } \\
\text { sebagian lainnya } \\
\text { menilai keputusan } \\
\text { pemerintah } \\
\text { tersebut } \\
\text { bertentangan } \\
\text { dengan nilai } \\
\text { demokrasi dan } \\
\text { reformasi. }\end{array}$ \\
\hline 3 & $\begin{array}{l}\text { Apakah tatanan } \\
\text { sosial } \\
\text { membutuhkan } \\
\text { ketidakberesan } \\
\text { sosial tersebut }\end{array}$ & $\begin{array}{l}\text { Nama besar FPI } \\
\text { sebagai ormas } \\
\text { yang ditakuti } \\
\text { dibuat tak berdaya } \\
\text { dengan } \\
\text { diterbitkannya SKB } \\
\text { yang } \\
\text { ditandatangani } \\
\text { enam menteri dan } \\
\text { kepala lembaga } \\
\text { negara. } \\
\text { FPI telah } \\
\text { dilemahkan. } \\
\text { FPI tidak boleh } \\
\text { melakukan aktvitas } \\
\text { lagi sebagai ormas } \\
\text { dan pelarangan } \\
\text { tersebut } \\
\text { berkekuatan } \\
\text { hukum yang harus } \\
\text { dipatuhi oleh FPI. }\end{array}$ \\
\hline 4. & $\begin{array}{l}\text { Mengidentifikasi } \\
\text { cara-cara yang } \\
\text { mungkin untuk } \\
\text { mengatasi } \\
\text { hambatan } \\
\text { tersebut }\end{array}$ & $\begin{array}{l}\text { Meski keputusan } \\
\text { pembubaran FPI } \\
\text { dianggap } \\
\text { berlawanan } \\
\text { dengan nilai-nilai } \\
\text { demokrasi dan } \\
\text { nilai-nilai reformasi } \\
\text { yang menjadi } \\
\text { prinsip bangsa } \\
\text { Indonesia, pihak } \\
\text { pemerintah } \\
\text { tampaknya } \\
\text { gentar akan hal } \\
\text { tersebut. }\end{array}$ \\
\hline
\end{tabular}




Pemerintah
berdalih langkah
pembubaran FPI
bertujuan menjaga
kepentingan
bangsa dan negara
yang lebih besar
yaitu menjaga
eksitensi ideologi
dan konsensus
dasar bernegara
yaitu Pancasila,
UUD 1945,
keutuhan NKRI,
dan Bhinekka
Tunggal Ika.

Sumber : Hasil penelitian tahun 2021

\section{Kesimpulan}

Dari empat berita yang dijadikan basis wacana dan dianalisis, semua menunjukkan satu hal bahwa kompas.com meletakkan FPI sebagai pihak yang salah dan keputusan pemerintah membubarkan FPI melalui SKB enam menteri dan kepala lembaga negara sebagai keputusan yang benar. Terlihat jelas pada perbendaharaan kata dan penggunaan istilah sudah menyiratkan keberpihakan kompas.com pada pemerintah. Kompas.com beberapa kali menggunakan pilihan diksi seperti "membubarkan", "bubarkan", "pembubaran", "menghentikan", "hentikan", "menolak", "disetujui", dan "melarang". Kompas.com juga menggunakan istilah seperti "de jure", "legal standing sebagai ormas", "ideologi Pancasila", "keputusan bersama", dan "menjaga kemaslahatan" yang memberi kesan bahwa keputusan pembubaran FPI sudah berjalan secara adil dan sudah sesuai aturan serta peraturan perundangundangan yang berlaku.

Argumen kompas.com bahwa apa yang dilakukan FPI selama ini sudah tidak sejalan dengan ideologi dan nilai-nilai yang diyakini dan dianut masyarakat. Dalih pemerintah bahwa langkah pembubaran
FPI bertujuan menjaga kepentingan bangsa dan negara yang lebih besar yaitu menjaga eksitensi ideologi dan konsensus dasar bernegara yaitu Pancasila, UUD 1945, keutuhan NKRI, dan Bhinekka Tunggal lka.

Sebagai saran, penelitian ini diharapkan dapat memberi tambahan pengetahuan kepada pembaca bahwa tentang tak ada peristiwa/realitas/fakta yang ditampilkan apa adanya, melainkan peristiwa/realitas/fakta tersebut telah dikonstruksi sedemikian rupa oleh media. Dan konstruksi media terlihat jelas melalui wacana yang termuat dalam teks berita. Selanjutnya, langkah pemerintah mengeluarkan keputusan pembubaran FPI bukan semata-mata untuk membentuk citra politik, melainkan sebagai bentuk upaya menjaga kesatuan NKRI dan menghentikan segala bentuk kekerasan di negeri ini, terutama yang dilakukan oleh ormas yang berkedok agama.

\section{Referensi}

Damayanti, Ninin Prima, dkk. (2003). Radikalisme Agama Sebagai Salah Satu Bentuk Perilaku Menyimpang: Studi Kasus Front Pembela Islam. Jurnal Kriminologi Indonesia, Vol 3 No 1, Juni. HIm 43-57.

Eriyanto. (2001). Analisis Wacana: Pengantar Analisis Teks Media. Yogyakarta. PT LkiS Printing Cemerlang.

(2012). Analisis Framing: Konstruksi, Ideologi dan Politik Media. Yogyakarta. PT LkiS Printing Cemerlang.

Hamad, Ibnu. (2004). Konstruksi Realitas Politik Dalam Media Massa: Sebuah Studi Critical Discourse Analysis 
Terhadap Berita-Berita Politik. Jakarta: Granit.

(2010). Komunikasi sebagai Wacana. Jakarta : La Tofi Enterprise.

(2014). Konstruksi Realitas Politik dalam Media Massa: Sebuah Studi Critical Discourse Analysis terhadap Berita-berita Politik, ed. 1. Jakarta. Granit.

Haryatmoko. (2016). Critical Discourse Analysis (Analisis Wacana Kritis): Landasan Teori, Metodologi dan Penerapan, Jakarta: PT Raja Grafindo Persada

Fairclough, Norman. (1992). Discourse and Social Change. Cambridge : Polity Press.

(1995). Critical Discourse Analysis: The Critical Study of Language. London: Longman.

(2010). Critical Discourse Analysis: The Critical Study of Language. 2nd Ed. New York: Routledge.

Faiz, F. (2017). Front Pembela Islam: Antara Kekerasan dan Kematangan Beragama, Kalam; 8 (2): 347-366.

Iskandar, Dudi., dan Rini Lestari. (2016). Mitos Jurnalisme. Yogyakarta. CV. Andi Offset

Jamhari, J. J. (2004). Gerakan Salafi Radikal di Indonesia. Jakarta: PT Raja Grafindo persada.

Lubis, Akhyar Yusuf. (2014). Teori dan Metodologi Ilmu Pengetahuan Sosial Budaya Kontemporer. Jakarta : Rajagrafindo Persada.

Mardikantoro, Hari Bakti, Muhammad Badrus Siroj, Esti Sudi Utami. (2019). Wacana Berita Korupsi di Surat
Kabar: Kajian Analisis Wacana Kritis Van Dijk Dalam Dimensi Praktik Sosial. Prosiding Seminar Nasional Pascasarjana UNNES.

Piliang, Yasraf Amir. (2003). Hantu-Hantu Politik dan Matinya Sosial. Solo: Tiga Serangkai.

Suryawati, Indah., dan Muhammad Syaid Aguatiar. (2018). Komisi Pemberantasan Korupsi Dalam Konstruksi Media Online (Analisis Wacana Kritis Berita Putusan Sidang Praperadilan Pertama Setya Novanto di Tribunnews.com Periode 30 September 2017). Jurnal Audience Vol. 1. No 2. HIm 107-122.

Syaefuddin, Machfud. (2014). Reingterpretasi Gerakan Dakwah Front Pembela Islam (FPI). Jurnal Ilmu Dakwah. Vol. 34, No.2, Juli Desember. HIm 259-276.

\section{Sumber online}

https://kbbi.web.id/bubar

http:/www.wahidinstitute.org/wahidid/images/upload/dokumen/40_mrori_ Bahasa

https://www.cnnindonesia.com/nasional/2 0201230114917-32587778/pembubaran-fpi-danpotensi-membesarnya-simpatipublik

https://nasional.kompas.com/read/2020/1 2/30/13205551/isi-lengkap-skbtentang-pembubaran-danpelarangan-kegiatan - fpi?page $=$ all

https://regional.kompas.com/read/2020/12 /31/21280281/fpi-dibubarkankarangan-bunga-ucapan-terimakasih-tersebar-di-surabaya 
https://nasional.kompas.com/read/2020/1 2/30/12522671/pembubaran-danpenghentian-aktivitas-fpi-diputus-6pejabat-tinggi-negara

https://nasional.kompas.com/read/2020/1 2/30/13533731/fpi-resmi-dibubarkanpenggunaan-simbol-hingga-atributdilarang

https://nasional.kompas.com/read/2020/1 2/30/13205551/isi-lengkap-skbtentang-pembubaran-danpelarangan-kegiatan - fpi?page $=$ all https://www.liputan6.com/news/read/445 0001/survei-pembubaran-fpidongkrak-kepuasan-publikterhadap-kinerja-jokowi

https://www.cnbcindonesia.com/news/202 01230133820-4-212551/simak-inialasan-lengkap-pemerintah-dibalik-pembekuan-fpi

https://www.voaindonesia.com/a/surveismrc-43-persen-orang-sukafpi/5677582.html 